\title{
NOTE
}

\section{Immunogenicity of a recombinant infectious hematopoietic necrosis virus glycoprotein produced in insect cells}

\author{
Kenneth D. Cain ${ }^{1, *}$, Scott E. LaPatra ${ }^{2}$, Bill Shewmaker ${ }^{2}$, Jerry Jones ${ }^{2}$, Katherine M. Byrne ${ }^{1}$, \\ Sandra S. Ristow ${ }^{1, * *}$ \\ ${ }^{1}$ Dept. of Animal Sciences, Washington State University, Pullman, Washington 99164-6351, USA \\ ${ }^{2}$ Clear Springs Foods, Inc., PO Box 712, Buhl, Idaho 83316, USA
}

\begin{abstract}
A recombinant infectious hematopoietic necrosis virus (IHNV) glycoprotein (G protein), produced in Spodoptera frugiperda (Sf9) cells following infection with a baculovirus vector containing the full-length $(1.6 \mathrm{~kb})$ glycoprotein gene, provided very limited protection in rainbow trout Oncorhynchus mykiss challenged with IHNV. Fish were injected intraperitoneally (i.p.) with $\mathrm{Sf} 9$ cells grown at $20^{\circ} \mathrm{C}\left(\operatorname{RecG}_{\text {low }}\right)$ or $27^{\circ} \mathrm{C}$ $\left(\mathrm{Rec}_{\mathrm{high}}\right)$ expressing the glycoprotein gene. Various antigen (Ag) preparations were administered to adult rainbow trout or rainbow trout fry. Sera collected from adult fish were evaluated for IHNV neutralization activity by a complement-dependent neutralization assay. Anti-IHNV neutralizing activity was observed in sera, but the percent of fish responding was significantly lower $(\mathrm{p}<0.05)$ in comparison to fish immunized with a low virulence strain of IHNV (LV-IHNV). A small number of fish immunized with $\operatorname{Rec} G_{\text {low }}$ or $R e c G_{\text {high }}$ possessed IHNV G protein specific antibodies (Abs) in their serum. Cumulative mortality (CM) of rainbow trout fry (mean weight, $1 \mathrm{~g}$ ) vaccinated by i.p. injection of freeze/thawed $\mathrm{Sf} 9$ cells producing $\mathrm{RecG}_{\mathrm{low}}$ was $18 \%$ in initial trials following IHNV challenge. This level of protection was significant ( $\mathrm{p}<0.05$ ) but was not long lasting, and neutralizing Abs were not detected in pooled serum samples. When trout fry (mean weight, $0.6 \mathrm{~g}$ ) were vaccinated with supernatant collected from sonicated $\mathrm{Sf} 9$ cells, $\mathrm{Sf} 9$ cells producing RecG $\mathrm{G}_{\text {low }}$, or $\mathrm{Sf} 9$ cells producing $\mathrm{Rec}_{\mathrm{high}}, \mathrm{CM}$ averaged $46 \%$. Protection was enhanced over negative controls, but not the positive controls ( $2 \% \mathrm{CM})$, suggesting that in the first trial soluble cellular proteins may have provided some level of non-specific protection, regardless of recombinant protein expression. Although some immunity was elicited in fish, and $R_{e c} G_{\text {low }}$ provided shortterm protection from IHNV, Ab-mediated protection could not be demonstrated. The results suggest that recombinant $G$ proteins produced in insect cells lack the immunogenicity associated with vaccination of fish with an attenuated strain of IHNV.
\end{abstract}

KEY WORDS: IHNV · Baculovirus · Recombinant glycoprotein Immunization - Rainbow trout

\footnotetext{
- Present address: Immunobiology Unit, University of Technology Sydney, Gore Hill, New South Wales 2065, Australia *Addressee for correspondence. E-mail: ristow@wsu.edu
}

Infectious hematopoietic necrosis virus (IHNV) is a rhabdovirus which causes acute disease primarily in juvenile sockeye salmon Oncorhynchus nerka, chinook salmon $O$. tshawytscha and rainbow trout $O$. mykiss (Wolf 1988). Infectious hematopoietic necrosis (IHN), the disease caused by this virus, results in large economic losses to public and private salmonid aquaculture operations. Control of IHN is achieved primarily through avoidance and no licensed commercial vaccines aimed at mass immunization of juvenile salmonids are available. Fish surviving infection with IHNV are generally resistant to re-infection and often possess IHNV neutralizing antibodies (Abs) (LaPatra et al. 1993, Ristow et al. 1993). The ability of the virus to elicit an immune response in salmonids suggested that vaccine development may be feasible and provide an effective method of disease control (Amend 1976). Experimental vaccines that provide varied levels of protection have been developed, but adaptation of these for large-scale use in commercial facilities has proven difficult (Gilmore et al. 1988, Leong \& Fryer 1993).

This study evaluates the potential of a baculovirus derived recombinant IHNV vaccine to elicit humoral immune responses in rainbow trout and provide protection against IHNV challenge. The expression of genes in insect cells using baculovirus vectors has been extensively utilized as a means of producing fulllength functionally active proteins. Unlike bacterial cells, insect cells have the ability to glycosylate proteins in a eukaryotic manner (Luckow \& Summers 1988, Luckow 1991, King \& Possee 1992). The glycoprotein (G protein) of IHNV is important in eliciting a protective immune response in fish (Engelking \& Leong 1989), and it is thought that a glycosylated $G$ protein may enhance immunity over non-glycosylated 
products. Expression of the glycoprotein gene of JHNV in insect cells was first achieved by Koener \& Leong (1990), but the ability of that antigen (Ag) to elicit immunity to IHNV was not reported. Lecocq-Xhonneux et al. (1994) found that rainbow trout injected with insect cell lysates producing a baculovirus derived recombinant viral hemorrhagic septicaemia virus (VHSV) glycoprotein developed neutralizing Abs and were protected from lethal challenge.

Initial characterization of the baculovirus product developed for this study has revealed interesting temperature-dependent properties (Cain et al. 1998). The recombinant glycoprotein, produced in insect cells Spodoptera frugiperda (Sf9) at $20^{\circ} \mathrm{C}\left(\operatorname{RecG}_{\mathrm{low}}\right)$, was shown to be transported and localized to the cell surface. In contrast, production at $27^{\circ} \mathrm{C}\left(\mathrm{RecG}_{\text {high }}\right)$ resulted in a protein which remained internalized within the cells. The results suggest that low temperature production may produce a more native product and agree with similar findings associated with the glycoprotein of VHSV (Lorenzen 1997). The objective of this study was to evaluate the ability of fish to elicit neutralizing antibodies and/or protective immunity following immunization with a baculovirus derived IHNV G protein produced in insect cells at 20 or $27^{\circ} \mathrm{C}$.

Materials and methods. Fish stocks were obtained from Clear Springs Foods Inc., Buhl, Idaho, USA, and all immunizations and challenges were conducted at their research facility. Adult rainbow trout with no history of an IHNV infection were obtained from research lots of fish, which had been maintained in outside raceways prior to being moved into the research laboratory. Juvenile rainbow trout were hatched and reared in ultra-violet (UV) light treated specific pathogen free (SPF) spring water prior to vaccination trials. All experiments were conducted in tanks supplied with UVtreated SPF spring water with an ambient temperature of $15^{\circ} \mathrm{C}$.

IHNV and assays: Monolayers of Epithelioma papulosum cyprini (EPC) cells (Fijan et al. 1983) were grown in minimal essential media (MEM, Gibco) supplemented with $10 \%$ fetal calf serum (FCS). An isolate of IHNV (220-90; LaPatra et al. 1991) and a low virulence IHNV strain (039-82; LaPatra et al. 1991) were propagated and assayed in EPC cells. Stocks of virus were obtained by harvest of cell culture lysate 6 to $8 \mathrm{~d}$ post-infection. A plaque assay (Burke \& Mulcahy 1980) was performed on a sub-sample of the lysate and aliquots were stored at $-75^{\circ} \mathrm{C}$. Low virulence IHNV (LV-IHNV) was used for immunizations of fish while isolate 220-90 was utilized for virus challenges and complement dependent neutralization assays (LaPatra et al. 1993). Purified IHNV (Round Butte I isolate; previously described in Hsu et al. 1986, Ristow \& Arnzen de Avila 1991) was used for immunoblotting analysis, while recombinant baculovirus stocks and Sf9 cells were maintained as previously described (see 'Materials and methods', Cain et al. 1998).

Immunization: Adult fish were tagged for individual identification prior to immunization. Simultaneously, serum was obtained from individual fish with no history of IHN and confirmed negative (titer $<20$ ) for IHNV neutralization titers by the complement-dependent neutralization assay (LaPatra et al. 1993). In Trials I-1 and I-2, 8 treatment groups were established, and 60 adult rainbow trout were immunized in each trial (Table 1). In Trial I-1, fish (mean weight, $1400 \mathrm{~g}$ ) were anesthetized with MS-222 (Argent chemical) and immunized by i.p. injection with $2 \mathrm{ml}$ of Ag. For those treatment groups receiving Freund's complete adjuvant (FCA), a 1:1 mixture consisting of $1 \mathrm{ml}$ of each preparation and $1 \mathrm{ml}$ of FCA was emulsified just prior to injection. Immunization Trial I-2 was designed similar to the first trial but fish were smaller (mean weight, $400 \mathrm{~g}$ ) and only $1 \mathrm{ml}$ of each preparation with or without FCA was injected. In both trials, fish were maintained in $1140 \mathrm{l}$ circular tanks. Serum was collected from individual fish in each trial at $3 \mathrm{wk}$ intervals and analyzed for IHNV neutralization titers. Fish were fasted $48 \mathrm{~h}$ prior to immunization or sera collection.

Vaccination and challenge: Vaccination trials (V-1 and $V$-2) were set up to evaluate protective immunity to IHNV conferred to rainbow trout fry following injection of preparations of $S f 9, R e c G_{\text {high }}$ and $R_{e c} G_{\text {low }}$ cells. Treatments were identical in the 2 trials; however, $\mathrm{Ag}$

Table 1. Oncorhynchus mykiss. Experimental design for adult rainbow trout immunized in trials (I-1 and I-2). Treatment groups received either freeze/thawed cells or supernatant from an equal concentration of cells subjected to sonication followed by removal of cellular debris by centrifugation $(10000 \times g)$ for $5 \mathrm{~min}$. LV-IHNV served as the positive control Ag in both immunization trials, while negative controls included phosphate-buffered saline (PBS) and/or Sf9 cells

\begin{tabular}{|c|c|c|c|}
\hline $\begin{array}{l}\text { Treatment groups } \\
\text { (RecG highi }[-1)^{\mathrm{a}}\end{array}$ & $N$ & $\begin{array}{l}\text { Treatment groups } \\
\left(\text { RecG }_{\text {lowi }}(1-2)^{b}\right.\end{array}$ & $\mathrm{N}$ \\
\hline Freeze/thawed cells & 10 & Freeze/thawed cell & 10 \\
\hline Freeze/thawed cells/FCA & 10 & Freeze/thawed cells & 10 \\
\hline Supernatant & 10 & Supernatant & 10 \\
\hline Supernatant/FCA & 10 & Supernatant/FCA & 10 \\
\hline LV-IHNV & 5 & LV-IHNV & 5 \\
\hline LV-IHNV/FCA & 5 & LV-IHNV/FCA & 5 \\
\hline PBS & 5 & $\mathrm{Sf} 9 / \mathrm{FCA}$ & 5 \\
\hline PBS/FCA & 5 & $\mathrm{PBS} / F C A$ & 5 \\
\hline \multicolumn{4}{|c|}{$\begin{array}{l}{ }^{\circ} \text { Cells producing } \text { RecG }_{\text {high }} \text { were harvested at various times } \\
\text { post-infection with recombinant baculovirus and pooled } \\
\text { cells were adjusted to a final concentration of } 3 \times 10^{6} \text { cells } \\
\mathrm{ml}^{-1} \\
{ }^{b} \text { Cells were adjusted to a final concentration of } 1 \times 10^{7} \text { cells } \\
\mathrm{ml}^{-1} \text { in PBS }\end{array}$} \\
\hline
\end{tabular}


ative controls immunized with PBS alone (Trial I-1) showed no serum neutralization activity in sera throughout the study, whereas fish injected with a low virulence strain of IHNV (LV-IHNV) seroconverted at a significant level.

The ability of serum Abs to bind to the viral or recombinant $G$ protein was evaluated by Western blot. Serum from a single fish immunized with RecG $_{\text {high }}$ emulsified in FCA that exhibited a neutralization titer of $\geq 160$ showed that $G$ specific Abs were elicited and capable of recognizing reduced and non-reduced viral $G$ protein (Fig. 1). The lower band identified in the blot of the reduced virus is likely an unglycosylated $G$ protein as it migrates at a similar molecular weight (MW). Serum tested by Western blot from fish immunized with preparations of $\mathrm{ReCG}_{\text {low }}$ also possessed Abs with the ability to recognize the IHNV G protein (data not shown). Lorenzen et al. (1993) demonstrated similar Ab development to the VHSV $G$ protein following immunization with a recombinant VHSV glycoprotein produced by bacterial expression. Serum collected from a fish immunized with LV-IHNV/FCA contained

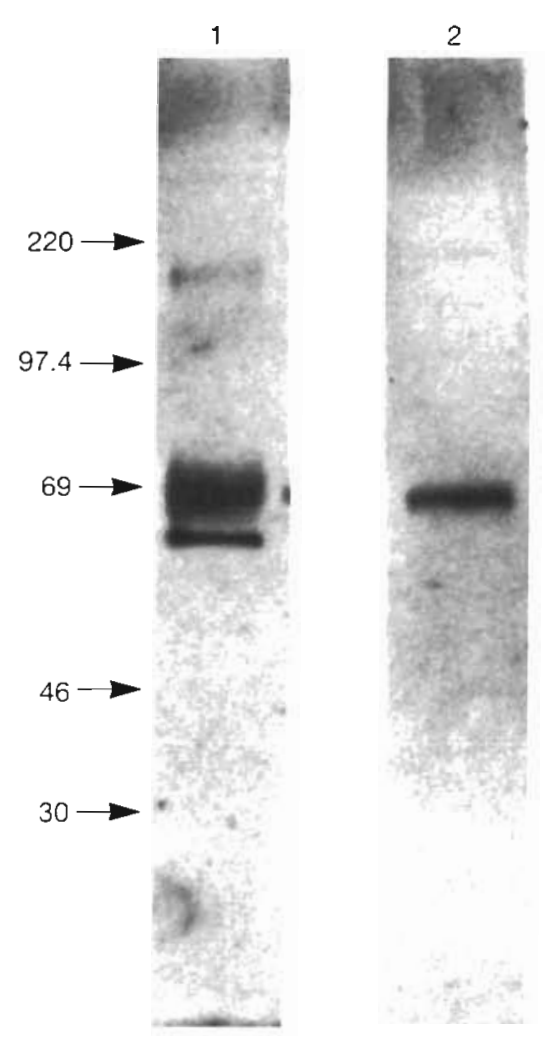

Fig. 1 Immunoblot of IHNV proteins. Nitrocellulose strips containing IHNV proteins were incubated with a 1:100 dilution of serum from a fish immunized with $\operatorname{Rec}_{\text {high. }}$ Strip 1 shows $A b$ recognition of wild-type IHNV $G$ protein electrophoresed under reduced conditions, and strip 2 shows $A b$ recognition of a non-denatured IHNV G protein
Abs that only weakly recognized the recombinant $G$ proteins, RecGlow and RecG $G_{\text {high }}$ (data not shown). Although Western blot results indicated that fish developed Abs to the G protein, the low percentage of fish seroconverting suggested that the antigenicity of recombinant preparations was low. It should be recognized that the use of a low virulence strain of virus would have established a subclinical infection in these fish resulting in continued stimulation of the immune system. Alternative positive controls for this experiment may have been a killed whole virus or purified viral $G$ protein. An IHNV virus with low viruluence was chosen as a control in this study principally because it readily elicits a humoral response measured by neutralizing Abs to IHNV and it is capable of producing protection upon challenge.

It was demonstrated that immunization by i.p. injection with freeze/thawed Sf9 cells producing RecGlow provided significant $(p<0.05)$ but short-term protection from IHNV challenge. Cumulative mortality in this treatment group was $18 \%$, and the degree of protection observed compares with similar studies of rainbow trout immunized by i.p. injection of Sf 9 cells producing a recombinant VHSV G protein emulsified in adjuvant and challenged by waterborne exposure to VHSV (Lecocq-Xhonneux et al. 1994). Although results from this initial trial appeared promising, identically treated fish challenged 5 wk post-booster ( $\mathrm{V}-1 \mathrm{~b}$ ) were susceptible to IHNV (Table 4). Additionally, neutralizing Abs were not detected in pooled serum samples collected from vaccinated stocks. The protection observed suggested that low temperature expression of the G protein was responsible for specific protection. Since a control consisting of $\mathrm{Sf} 9$ cells grown at $20^{\circ} \mathrm{C}$ was not included in this first vaccination trial (V-1a and V-1b), it cannot be ruled out that some property induced by the low temperature cultivation of cells (without baculovirus infection) may have been responsible for enhanced protection. Virus was re-isolated from 93 and $90 \%$ of mortalities sampled in the first trial and mean virus titers were $4.8 \times 10^{6} \mathrm{pfu} \mathrm{m}^{-1}$ and $2.6 \times$ $10^{6} \mathrm{pfu} \mathrm{ml}^{-1}$, respectively. Since long-term immunity is a critical requirement in the development of an efficacious vaccine (Leong \& Fryer 1993), our initial results raised concern.

Additional trials ( $\mathrm{V}-2 \mathrm{a}$ and $\mathrm{V}-2 \mathrm{~b}$ ) to evaluate the ability of the 'sonicated' Ag to provide protection from virus challenge were conducted. Sonication of cells was considered important since the development of an immersion-based vaccine would likely require the cellular dissociation and solublization of the $\mathrm{G}$ protein. It is known that when the G protein of IHNV is stripped from the surface of the virus by treatment with Triton $\mathrm{X}-100$ it remains immunogenic to fish (Engelking \& Leong 1989). Sonication allowed the dissociation of $\mathrm{Ag}$ 
Table 4. Oncorhynchus mykiss. Protection of rainbow trout fry following IHNV challenge. Trials designated as $V-1 \mathrm{a}$ and $\mathrm{V}-2 \mathrm{a}$ indicate data were collected from IHNV challenge 2 wk post-booster, while $V-1 b$ and $V-2 b$ indicate data were collected following IHNV challenge of identically treated fish $5 \mathrm{wk}$ post-booster. $N$ : Replicate groups. Significant differences $(p<0.05)$ in cumulative percent mortality are indicated by different letters in subscript. Relative percent survival (RPS, Johnson et al. 1982) of vaccinated over control fish was determined by the formula: RPS $=[1-(\%$ loss of vaccinated fish $/ \%$ loss of controls $)] \times 100$. Note: Positive control fish were passively immunized with $50 \mu$ l of a 1:25 dilution of rabbit anti-IHNV antiserum $24 \mathrm{~h}$ prior to challenge, while negative control fish received only tissue culture media

\begin{tabular}{|c|c|c|c|c|c|}
\hline Trial & Treatment & Booster & $\mathrm{N}$ & $\begin{array}{c}\text { Mortality } \\
(\%)\end{array}$ & RPS \\
\hline $\begin{array}{l}\text { V-1a } \\
" \\
" \\
"\end{array}$ & $\begin{array}{l}\left.\text { Freeze/thawed cells (RecG } G_{\text {hugh }}\right) \\
\text { Freeze/thawed cells }\left(\operatorname{Rec}_{\text {low }}\right) \\
\text { Freeze/thawed cells (Sf9) } \\
\text { (+) control (rabbit anti-IHNV) } \\
(-) \text { control (tissue culture media) }\end{array}$ & $\begin{array}{l}\text { Supernatant } \\
\text { Supernatant } \\
\text { Supernatant } \\
\text { Supernatant } \\
\text { Supernatant }\end{array}$ & $\begin{array}{l}27+25 \\
27+30 \\
25+25 \\
25+24 \\
25+25\end{array}$ & $\begin{array}{l}33_{\mathrm{a}} \\
18_{\mathrm{b}} \\
46_{\mathrm{a}} \\
6_{\mathrm{b}} \\
40_{\mathrm{a}}\end{array}$ & $\begin{array}{l}18 \\
56 \\
- \\
85\end{array}$ \\
\hline $\begin{array}{l}\mathrm{V}-1 \mathrm{~b} \\
" \\
" \\
"\end{array}$ & $\begin{array}{l}\left.\text { Freeze/thawed cells (RecG }{ }_{\text {high }}\right) \\
\text { Freeze/thawed cells }\left(\operatorname{Rec} G_{\text {low }}\right) \\
\text { Freeze/thawed cells (Sf9) } \\
\text { (+) control (rabbit anti-IHNV) } \\
\text { (-) control (tissue culture media) }\end{array}$ & $\begin{array}{l}\text { Supernatant } \\
\text { Supernatant } \\
\text { Supernatant } \\
\text { Supernatant } \\
\text { Supernatant }\end{array}$ & $\begin{array}{l}24+23 \\
26+24 \\
25+25 \\
26+26 \\
26+26\end{array}$ & $\begin{array}{l}58_{a} \\
52_{a} \\
58_{a} \\
10_{b} \\
44_{a}\end{array}$ & $\begin{array}{l}- \\
- \\
- \\
78 \\
-\end{array}$ \\
\hline $\begin{array}{l}\mathrm{V}-2 \mathrm{a} \\
" \mathrm{n} \\
" \\
"\end{array}$ & $\begin{array}{l}\text { Supernatant }\left(\operatorname{Rec}_{\mathrm{G}_{\text {high }}}\right) \\
\text { Supernatant }\left(\mathrm{RecG}_{\mathrm{low}}\right) \\
\text { Supernatant (Sf9) } \\
\text { (+) control (rabbit anti-IHNV) } \\
\text { (-) control (tissue culture media) }\end{array}$ & $\begin{array}{l}\text { Supernatant } \\
\text { Supernatant } \\
\text { Supernatant } \\
\text { Supernatant } \\
\text { Supernatant }\end{array}$ & $\begin{array}{l}24+24 \\
25+25 \\
24+20 \\
24+24 \\
25+25\end{array}$ & $\begin{array}{l}46_{\mathrm{cd}} \\
48_{\mathrm{d}} \\
43_{\mathrm{d}} \\
2 \mathrm{~b} \\
84_{\mathrm{c}}\end{array}$ & $\begin{array}{l}45 \\
43 \\
49 \\
98 \\
-\end{array}$ \\
\hline $\begin{array}{l}\mathrm{V}-2 \mathrm{~b} \\
" \\
" \\
"\end{array}$ & $\begin{array}{l}\text { Supernatant }\left(\operatorname{Rec}_{\mathrm{h}_{\text {high }}}\right) \\
\text { Supernatant }\left(\operatorname{Rec} \mathrm{G}_{\mathrm{low}}\right) \\
\text { Supernatant (Sf9) } \\
\text { (+) control (rabbit anti-IHNV) } \\
\text { (-) control (tissue culture media) }\end{array}$ & $\begin{array}{l}\text { Supernatant } \\
\text { Supernatant } \\
\text { Supernatant } \\
\text { Supernatant } \\
\text { Supernatant }\end{array}$ & $\begin{array}{l}24+23 \\
26+24 \\
25+25 \\
26+26 \\
26+26\end{array}$ & $\begin{array}{l}68_{\mathrm{d}} \\
31_{\mathrm{d}} \\
44_{\mathrm{cd}} \\
8 \mathrm{c} \\
39_{\mathrm{d}}\end{array}$ & $\begin{array}{c}- \\
21 \\
- \\
78 \\
-\end{array}$ \\
\hline
\end{tabular}

The results of this study provide evidence that a recombinant IHNV G protein produced in insect cells may elicit limited virus neutralizing Abs and may provide short duration protection in rainbow trout; however, these responses appear limited, and further analysis and purification of these recombinant products is needed. The short-term protection conferred by immunization in the first trial with $\mathrm{RecG}_{\text {low }}$ appeared interesting, but in retrospect, immunogenicity of $\operatorname{Rec}_{\text {high }}$ and $R_{e c} G_{\text {low }}$ appears minimal. The properties of both $G$ proteins tested here differ from the native IHNV glycoprotein (Cain et al. 1998), which may explain the lack of immunostimulatory properties observed. Temperature manipulations during expression of recombinant proteins could prove crucial in future vaccine development, and as more information is obtained about the G protein of IHNV, a better immunogen may be developed. Results presented in this study emphasise the need for a greater understanding of the complex interactions of the fish immune system with the glycoprotein of IHNV. from the cell membrane as demonstrated by use of $G$ specific MAbs in Western and dot blot analysis of sonicated supernatant (data not shown). In vaccination Trial V-2a, fish immunized with supernatant from sonicated Sf9 cells, Sf9 cells producing RecG high, or Rec $G_{\text {low }}$ exhibited cumulative mortalities of 43,46 , and $48 \%$, respectively. Although this initial level of protection was significant $(p<0.05$ ) when compared to mortalities in the negative control groups, it was noi comparable to positive control groups which exhibited cumulative mortalities of only $2 \%$ (Table 4 ). Since protection in this trial was associated with all groups immunized with insect cells, regardless of recombinant protein expression, it is possible that non-specific components of the immune system were stimulated which enhanced cell-mediated immunity over negative control fish. When the challenge was repeated at $5 \mathrm{wk}$ ( $V$-2b), no protection was observed in fish from any of the vaccinated groups, but positive control groups again exhibited significantly lower $(\mathrm{p}<0.05)$ mortality than negative controls. In Trials $V-2 a$ and $V-2 b$, virus was re-isolated from 95 to $96 \%$ of mortalities sampled, and ranged in mean titer from $3.7 \times 10^{6} \mathrm{pfu} \mathrm{ml}^{-1}$ to $5.1 \times 10^{6} \mathrm{pfu} \mathrm{ml}^{-1}$, respectively.
Acknowledgements. The authors extend their appreciation to Dr Randy MacMillan for the opportunity to perform experiments at the research facility at Clear Springs Foods. We thank Alberta Brassfield for her work with construction of the recombinant baculovirus vectors. In addition, we thank Sunshine Walker, and Brenda Vincent for their technical assistance, and Scott Williams for his help in statistical analysis of data. This scientific paper originates from the College of Agriculture and Home Economics Research Center at Washington State University. This work was supported in part by grants 96-38500-2674 and 97-38500-4041 from the United States Department of Agriculture to the Western Regional Aquaculture Center.

\section{LITERATURE CITED}

Amend DF (1976) Prevention and control of viral diseases of salmonids. J Fish Res Bd Can 33:1059-1066

Burke JA, Mulcahy D (1980) Plaquing procedure for infectious hematopoietic necrosis virus. J Appl Environ Microbiol 39:872-876

Cain KD, Byrne KM, Brassfield A, LaPatra SE, Ristow SS (1999) Temperature-dependent characteristics of a recombinant infectious hematopoietic necrosis virus glycoprotein expressed in insect cells. Dis Aquat Org 36:1-10

DeLuca D, Wilson M, Warr GW (1983) Lymphocyte heterogeneity in the trout, Salmo gairdneri, defined with monoclonal antibodies to IgM. Eur J Immunol 13:546-551 
Engelking HM. Leong JC (1989) The glycoprotein of infectious hematopoietic necrosis virus elicits neutralizing antibody and protective responses. Virus Res 13:213-230

Fijan N, Sulimanovic D, Bearzotti M, Muzinic D, Zwillenberg LD, Chilmonczyk S, Vauthaucrot JF, de Kinkelin P (1983) Some properties of the epithelioma papillosum cyprini (EPC) line from common carp Cyprinus carpio. Ann Virol $134: 207-220$

Gilmore RD, Engelking HM, Manning DS, Leong JC (1988) Expression in E.coli of an epitope on the glycoprotein of infectious hematopoietic necrosis virus protects against viral challenge. Biotechnology 6:295-300

Hsu Y, Engelking MH, Leong JC (1986) Occurrence of different types of infectious hematopoietic necrosis virus in fish Appl Environ Microbiol 52:1353-1361

Johnson, KA, Flyhn, JK, Amend DF (1982) Onset of immunity in salmonid fry vaccinated by direct immersion in Vibrio anguillarum and Yersinia rucken bacterins. J Fish Dis 5: $197-205$

King LA, Possee RD (1992) The baculovirus expression system: a laboratory guide. Chapman \& Hall, London

Koener JF, Leong JC (1990) Expression of the glycoprotein gene from a fish rhabdovirus by using baculovirus vectors. J Virol 64:428-430

LaPatra, SE, Rohovec JS, Fryer JL (1989) Detection of infectious hematopoietic necrosis virus (IHNV) in fish mucus. Fish Pathol 24(4):197-202

LaPatra SE, Lauda KA, Morton AW (1991) Antigenic and virulence comparison of eight isolates of infectious hematopoietic necrosis virus from the Hagerman Valley, Idaho, USA. In: Fryer JL (ed) Proceedings of the Second International Symposium on Viruses of Lower Vertebrates. Oregon State Univ, Corvallis, p 125-129

LaPatra SE, Turner T, Lauda KA, Jones GR, Walker S (1993) Characterization of the humoral response of rainbow trout to infectious hematopoietic necrosis. J Aquat Anim Health $5: 165-171$.

Editorial responsibility: Jo-Ann Leong,

Corvallis, Oregon, USA
Lecocq-Xhonneux F, Thiry M, Dheur I, Rossius M, Vanderheijden N, Martial J, de Kinkelin P (1994) A recombinant viral haemorrhagic septicaemia virus glycoprotein expressed in insect cells induces protective immunity in rainbow trout. J Gen Virol 75:1579-1587

Leong JC, Fryer JL (1993) Viral vaccines for aquaculture. Annu Rev Fish Dis 3:225-240

Lorenzen $N$ (1997) The glycoprotein of VHS virus. In: New approaches to viral diseases of aquatic animals. Proceedings of the NRIA International Workshop Kyoto, p 58-65

Lorenzen $N$, Olesen NJ, Jorgensen PEV, Etzerodt M, Holtet TL, Thogersen HC (1993) Molecular cloning and expression in Escherichia coli of the glycoprotein gene of VHS virus, and immunization of rainbow trout with the recombinant protein. J Gen Virol 74:623-630

Luckow VA (1991) Cloning and expression of heterologous genes in insect cells with baculovirus vectors. In: Prokip A, Bajpai RK, Ho C (eds) Recombinant DNA technology and applications. McGraw-Hill, New York, p 97-152

Luckow VA, Summers MD (1988) Signals important for highlevel expression of foreign genes in Autographa californica nuclear polyhedrosis virus expression vector Virology 170:31-39

Ristow SS, Arnzen de Avila J (1991) Monoclonal antibodies to the glycaprotein and nucleoprotein of infectious hematopoietic necrosis virus (IHNV) reveal differences among isolates of the virus by fluorescence, neutralization and electrophoresis. Dis Aquat Org 11:105-115

Ristow SS, de Avila J, LaPatra SE, Lauda K (1993) Detection and characterization of rainbow trout antibody against infectious hematopoietic necrosis virus. Dis Aquat Org 15: $109-114$

Wolf K (1988) Infectious hematopoietic necrosis. In: Wolf $\mathrm{K}$ (ed) Fish viruses and fish viral diseases. Cornell University Press, Ithaca, p 83-114

Accepted: October 6, 1998

Proofs received from author(s): April 9, 1999 